\title{
MÁLFREGNIR
}

\section{Nýjar ritreglur 2016}

Hinn 6. júní 2016 gaf mennta- og menningarmálaráðherra út auglýsingu nr. 695 um setningu íslenskra ritreglna. Auglýsingin birtist í B-deild Stjórnartíðinda 10. ágúst 2016.

Ritreglurnar voru birtar sem fylgiskjal með auglýsingu ráðherra. Jafnframt féll úr gildi auglýsing um íslenska stafsetningu, nr. 132/1974, með síðari breytingum.

Reglurnar gilda um stafsetningarkennslu í skólum og útgefið efni á vegum hins opinbera.

Auglýsing ráðherra var birt með stoðí 2. málsgrein 6. greinar laga nr. 61/2011 um stöðu íslenskrar tungu og íslensks táknmáls. Sú málsgrein hljóðar svo: „Hlutverk Íslenskrar málnefndar er að veita stjórnvöldum ráđgjöf um málefni íslenskrar tungu á fræðilegum grundvelli og gera tillögur til ráðherra um málstefnu, auk pess að álykta árlega um stöðu íslenskrar tungu. Málnefndin getur átt frumkvæði að ábendingum um pað sem vel er gert og pað sem betur má fara við meðferð íslenskrar tungu á opinberum vettvangi. Íslensk málnefnd semur íslenskar ritreglur sem gilda m.a. um stafsetningarkennslu í skólum og ráðherra gefur út. Grundvallarbreytingar á ritreglum eru háðar sampykki ráðherra."

Útgáfa auglýsingarinnar um íslenskar ritreglur markar talsverð tímamót í sögu íslenskrar málstöðlunar og íslenskukennslu. Hér hefur ráðherra í fyrsta sinn gefið út ritreglur í samræmi við núgildandi lög um Íslenska málnefnd.

Á vef Îslenskrar málnefndar kemur fram að vinnuhópar á vegum nefndarinnar hafi unnið að endurskoðun eldri ritreglna árin 2009_ 2015 og að Íslensk málnefnd hafi skilað drögum að nýjum ritreglum

Orð og tunga 19 (2017), 215-217. @ Stofnun Árna Magnússonar í íslenskum fræðum, Reykjavík. 
til mennta- og menningarmálaráđuneytis 5. apríl 2016 (Íslensk málnefnd 2016a). Eftir gildistöku auglýsingarinnar lét málnefndin hanna nýtt pdf-skjal (67 bls.) með ritreglunum (Íslensk málnefnd 2016b).

Engar grundvallarbreytingar urðu á íslenskri stafsetningu með tilkomu nýju ritreglnanna. Stafsetningin er eftir sem áđur reist fremur á uppruna en framburði: aðgreining $y, y, e y$ og $i, i, e i$; aðgreining $n$ og $n n$ í áherslulausum atkvæðum; stofnreglunni svonefndu er fylgt (t.d. grimmd með mm, sbr. grimmur) og par fram eftir götunum.

Enda pótt ekki hafi verið um að ræða neinar grundvallarbreytingar frá peim stafsetningarreglum sem áđur giltu er mjög margt hér skýrar fram sett og nánar útfært frá pví sem var í auglýsingunni frá 1974 og breytingum á henni 1977. Í pví efni virðist nokkuð byggt á peim ritreglum sem teknar voru saman í Íslenskri málstöð á vegum Íslenskrar málnefndar fyrir rúmum áratug og birtust í Stafsetningarorðabókinni sem málnefndin gaf út 2006. Markmið peirra ritreglna var að skýra eftir föngum og fylgja eftir págildandi auglýsingu ráðherra um íslenska stafsetningu og leitast við að bæta framsetningu hennar, m.a. með fjölda dæma.

Efnislegar breytingar 2016, frá auglýsingunni 1974, meðbreytingum 1977, eru sem sé í raun frekar litlar (sbr. einnig Jóhannes B. Sigtryggsson 2016) en pær varða pá helst ritun lítils og stórs upphafsstafs í stöku tilfellum (svo sem heiti fylgismanna stjórnmálaflokka: áđur sjálfstæðismaður en nú Sjálfstæðismaður) og ritun í einu eða fleiri orðum (m.a. að orðasambönd með konar og kyns skuli nú eingöngu rita í samræmi við uppruna, p.e. hvert orð út af fyrir sig, og að meðfram skuli nú rita í einu orði, p.e. á sama hátt og áfram og umfram).

\section{Heimildir}

Auglýsing um íslenska stafsetningu nr. 132/1974.

Auglýsing um íslenska stafsetningu nr. 261/1977.

Auglýsing um setningu íslenskra ritreglna nr. 695/2016. 6. júní 2016. https:// www.menntamalaraduneyti.is/media/frettatengt2016/Auglysing-umislenskar-ritreglur.pdf

Auglýsing um setningu íslenskra ritreglna nr. 695/2016. 10. ágúst 2016. Stjórnartíðindi. B-deild. www.stjornartidindi.is

Íslensk málnefnd. 2016a. Ritreglur. http://islenskan.is/ritreglur-im

Íslensk málnefnd. 2016b. Ritreglur. Auglýsing mennta- og menningarmálaráduneytis nr. 695/2016 mеð leiðréttingum. http://islenskan.is/images/ritreglurIM-2016.pdf 
Jóhannes B. Sigtryggsson. 2016. Greinargerð um helstu breytingar á ritreglum. Skíma 39:40-41.

Lög um stöðu íslenskrar tungu og íslensks táknmáls nr. 61/2011.

Stafsetningarorðabókin (ritstj. Dóra Hafsteinsdóttir). 2006. Ritreglur, bls. 673736. Reykjavík: Îslensk málnefnd / JPV.

Ritstj. 